\title{
Fear of death and polarization: political consequences of the COVID-19 pandemic
}

\author{
Carlos Pereira ${ }^{1}$ \\ Amanda Medeiros 1 \\ Frederico Bertholini 2 \\ 1 Fundação Getulio Vargas / Brazilian School of Public and Business Administration, Rio de Janeiro / RJ - Brazil \\ 2 Universida de Brasília / Institute of Political Science, Brasília / DF - Brazil
}

Humanity has always been tormented with the end of existence. On some occasions, such as the current COVID-19 pandemic, this affliction is pronounced. To what extent can fear of death alter individuals' political perceptions and beliefs? It is in this context of uncertainties and fears that we investigate how Brazilian society has been evaluating its leaders, especially concerning the policy of social distancing. The COVID-19 pandemic changed the axes of political polarization. On the one hand, governors, mayors, and legislators are concerned about the risks of a collapse of the health system. On the other, President Jair Bolsonaro focused primarily on the negative economic consequences of the pandemic. Through an opinion poll, we identified that "fear of death" diminished the ideological polarization that has existed in Brazil since Jair Bolsonaro's election. Contrary to what many expected, voters who identified themselves as right-wing and center-right - supposedly, the core of Bolsonaro's voters - refused to follow the president's recommendation of relaxing social distancing policies and considered his performance inappropriate during the pandemic. We also show that different income levels did not influence this change in behavior.

Keywords: COVID-19; ideology; identity; political polarization; populism.

\section{0 medo da morte flexibiliza perdas e aproxima polos: consequências políticas da pandemia da COVID-19 no Brasil}

Desde sempre a humanidade se aflige com o fim da existência. Em algumas ocasiões, como a atual pandemia do novo coronavírus, percebemos sua presença mais de perto. Até que ponto o medo da morte pode alterar percepções e crenças dos indivíduos? É nesse contexto de incertezas e medos que decidimos investigar de que modo a sociedade brasileira vem avaliando seus governantes, sobretudo em relação à política de isolamento social. A pandemia da COVID-19 alterou os eixos da polarização política. De um lado, governadores, prefeitos e legisladores preocupados com os riscos de estrangulamento do sistema de saúde causado pela pandemia. De outro, o presidente Jair Bolsonaro, focado primordialmente nas consequências econômicas negativas da política de isolamento social. Por meio de uma pesquisa de opinião, identificamos que o "medo da morte" diminuiu a polarização ideológica existente no Brasil desde a eleição de Jair Bolsonaro à presidência da República. Ao contrário do que muitos esperavam, os eleitores que se auto-identificaram como de direita e centro-direita - supostamente, o núcleo de eleitores de Bolsonaro - rejeitaram seguir a recomendação e avaliam mal a performance de seu líder.

Palavras-chave: COVID-19; ideologia; identidade; polarização política; populismo.

[Translated version] Note: All quotes in English translated by this article's translator.

We would like to thank the newspaper O Estado de S. Paulo for the collaboration and dissemination of the field research to its readers. Preliminary versions of this article were presented in webinars (https://www.youtube.com/watch?v=LZMTFyvUZ7A\&feature=youtu. be\&fbclid=IwAR2hid1ja80ZR588nuYClwdrZbcNDbCtTjxUoUXUcQ0C4mHX78qg9RiMEEE) with the participation of Sérgio Abranches, Mônica De Bole, Marcus Melo, Pedro Doria, Maria Hermínia Tavares de Almeida, and Daniel Bramatti. We are also grateful for the webinar's participants' comments and for the suggestions by Rafael Goldszmidt and Eduardo Andrade. 


\title{
El miedo a la muerte alivia las pérdidas y acerca los polos: consecuencias políticas de la pandemia de COVID-19 en Brasil
}

La humanidad siempre se ha afligido por el fin de la existencia. En algunas ocasiones, como en la pandemia actual del nuevo coronavirus, esa aflicción se hace más presente. ¿Hasta qué punto puede el miedo a la muerte alterar las percepciones y creencias de los individuos? Es en este contexto de incertidumbres y temores que decidimos investigar cómo la sociedad brasileña ha evaluado a sus líderes, especialmente con relación a la política de aislamiento social. La pandemia de COVID-19 cambió los ejes de polarización política. Por un lado, gobernadores, alcaldes y legisladores preocupados por los riesgos de estrangular el sistema de salud a causa de la pandemia. Por otro, el presidente Jair Bolsonaro centrado principalmente en las consecuencias económicas negativas de la política de aislamiento social. A través de una encuesta de opinión, identificamos que el "miedo a la muerte" disminuyó la polarización ideológica que ha existido en Brasil desde la elección de Jair Bolsonaro a la presidencia de la República. $\mathrm{Al}$ contrario de lo que muchos esperaban, los electores que se identificaron como de derecha y centroderecha, supuestamente los principales votantes de Bolsonaro, rechazaron cumplir con la recomendación y juzgaron mal el desempeño de su líder. También mostramos que este cambio en el comportamiento no fue influenciado por diferentes niveles de ingresos.

Palabras clave: COVID-19; ideología; identidad; polarización política; populismo.

\author{
"Who are you? \\ I am Death. \\ Have you come to fetch me? \\ I have long walked at your side. \\ That I know. \\ Are you ready? \\ You all say that, but I leave no respite."
}

My body is, not myself. Wait a moment...

(The Seventh Seal, Ingmar Bergman, 1956)

\section{INTRODUCTION}

The epilogue above is the initial dialogue between Death and Antonius Block, a knight who returns from the Crusades in the Middle Ages and finds his homeland completely devastated by the black plague. The central theme of the Seventh Seal, Ingmar Bergman's masterpiece, is the fear of death. When the knight faces Death, he proposes a deal: a game of chess. While playing, the man gains time, because he knows that it would not be possible to win, since Death is inevitable, which is why it is impossible to escape his destiny. So the best way out would be to postpone it as much as possible.

The COVID-19 pandemic was an exogenous shock of great magnitude, equivalent to the displacement of tectonic plates. Actors and political leaders had extreme reactions not only in Brazil but in several countries around the world.

On the one hand, those most concerned with the speed of contagion, the severity of the disease, and the risk of death have followed the recommendations of the World Health Organization (WHO), which advises social distancing, even in the face of the negative consequences for the economy. In the countries that presented cases of the disease, almost all leaders of countries that have presented 
cases of the disease have adopted social distancing measures. This has also been the case, for example, with governors, mayors, and main legislative leaders in Brazil.

On the other hand, some countries have witnessed segments of the population and some governments minimizing the pandemic's virulence and consequences for health, concerned about the adverse economic effects generated by social distancing measures. ${ }^{1}$

The Brazilian president, Jair Bolsonaro, has been one of the main supporters of this strategy. Aligned with this position, presidents of Nicaragua, Daniel Ortega; Belarus, Alexander Lukashenko; and Turkmenistan, Gurbanguly Berdimuhamedow, also refused to enact measures of social distancing. At the beginning of the pandemic, the presidents of the United States, Donald Trump; Mexico, López Obrador; Russia, Vladimir Putin; and the Italian Prime Minister, Giuseppe Conte, were also reluctant to support social distancing, but ended up changing their position and started to advocate that the population stay at home.

According to Kingstone and Power (2017), there has been a strong increase in political polarization in Brazil since 2013, triggered by nationwide mass demonstrations that occurred that year. For Hunter and Power (2019), the increasing polarization was visible throughout all social strata, including the vulnerable population and the political and economic elite, and it took over the country during the 2018 elections. At that time, the number of voters who chose a candidate from one of the poles approached that of those who expressed a strong dislike for the opposing candidate. One of the poles was represented by the Workers' Party (PT), standing for the traditional politics eroded by successive corruption scandals. The other pole was Bolsonaro, who adopted the notion of "antipetismo" (AntiPT) (Bello, 2019; Samuels \& Zucco, 2018) and grasped the expectations of another social group and promised to deliver "new politics" based on anti-establishment.

This game of polarized groups was in relative "balance" until the COVID-19 pandemic, with each group becoming stronger based on the radical opposition of political identities and preferences. The groups did not dialogue with each other and tended to consume information that only reinforced their previous beliefs. At the same time, they rejected any information that contradicted previous values, so they did not access information that could put their respective "comfort zones" at risk.

Could it be possible to imagine a change in the axis of political polarization in Brazil, bringing together voters who were once located at opposite poles? Can fear of death bring new axes of polarization to emerge beyond the clash between left and right-wing?

This study addresses these questions through an opinion poll that explored people's position regarding social distancing measures, and their evaluation about the president and the governors in conducting the COVID-19 containment policy.

The main hypothesis is that the pandemic has altered the axes of political polarization in the country, bringing together the ideological poles. In other words, COVID-19 caused significant segments of voters to change their political perception due to their "fear of death."

\footnotetext{
${ }^{1}$ The dichotomy between 'preserving health' versus 'preserving economy', although factually false as demonstrated by experts such as Martins (2020) and Pereira (2020), permeates the political discourses of those who oppose social distancing. For Ajzenman, Cavalcanti, and Da Mata (2020), the political discourses based on this false dichotomy can greatly affect the success of social distancing measures.
} 
The results confirm that a significant portion of voters self-identified as center-right and rightwing support the social distancing policy, in the opposite direction to the position defended by President Bolsonaro, changing the terms of polarization in the country and suggesting its decrease. ${ }^{2}$ Such voters also positively evaluate the performance of the governors of their respective states and negatively that of the president during the pandemic. In addition, the low-income sectors, in theory more vulnerable, did not present systematic opposition to the social distancing policy when compared to people belonging to other income groups.

This research brings empirical and theoretical contributions on the role and limits of ideology and identity affinity in shaping political behavior in polarized environments. Ideology, which is part of a person's identity (Huddy, 2001; Iborra, 2005; Teles, 2009), works as a cognitive and protective shortcut, facilitating that those who share beliefs and values make similar choices (Huckfeldt et al., 1999). We argue that in extreme situations - for example, when the lives of people and their loved ones are at risk - ideological and identity values may cease to be crucial to making choices. In other words, identities or ideologies become malleable and susceptible to adjustments and changes. Extreme situations can create problems for those who belong to a certain group, because sometimes the natural choice - 'natural' according to the ideology that is part of their identity and keeps them linked to a group - may represent a threat to their own lives.

The next section presents our theory based on a critical dialogue with the literature on populism and identity. The third section describes the methodology and descriptive statistics. In the fourth and fifth sections, we present the main results of the research. In the final section, we conclude the article, highlighting the main findings.

\section{POPULISM OF IDENTITY}

The combination of a serious economic crisis and daily exposure to successive corruption scandals generated, of a large part of the Brazilian voters, the perception of politics as something dirty. By directly associating the specific style of coalitional presidentialism practiced by the Workers Party (PT) governments with corruption, Bolsonaro fed the electorate with a kind of aversion to politics itself, thus filling an open space for the populists' emergence (Bakker, Rooduijn, \& Schumacher, 2016; Busby, Gubler, \& Hawkins, 2019; Hawkins, Kaltwasser, \& Andreadis, 2020).

President Bolsonaro sought to fulfill the expectations of "cleansing" Brazilian politics by building a platform that was initially anti-PT, but essentially anti-party, defending the idea that all acronyms and their members would be equally part of a corrupt elite. The electoral viability of this belief occurs through the identity framework that denies the institutions and praises the direct connection between the political leader and the voters. The background of this ideology/identity is the myth-making process and the homogenization of the categories "elites" and "people," identified as antagonistic (Bos et al., 2020; Mudde, 2004; Mudde \& Kaltwasser, 2012).

Once elected, Bolsonaro refused to build a coalition and chose to govern as a minority. To circumvent this fragility, he sought to establish direct connections with voters, adopting a kind of plebiscitary

\footnotetext{
${ }^{2}$ Not opposing social distancing, however, does not necessarily mean resigning support for the president or that these voters would be opposing Bolsonaro in all his policies or dimensions. We would like to thank RAP reviewers for pointing out this nuance.
} 
presidentialism (Conaghan, 2008). In Congress, he worked by forming cyclical majorities to vote aligned with the executive branch's preferences, constraining legislators through pressure from public opinion. By adopting this strategy, which Kernell (2006) classifies as "going public," Bolsonaro governed in a permanent campaign of polarization. The conspiratorial tone has been a fundamental part of this government crusade against indefinite enemies that emerge every day (Kovic \& Caspar, 2019).

The systematic denial of traditional instruments of government left Bolsonaro little alternative, before and during the pandemic. The uninterrupted and radical mobilization of his most loyal voters continued to be the standard model of the president's governance. His 'plebiscitary populism' became a strategy for strengthening identity and protecting the core of his constituency of voters.

As mentioned before, ideology is part of an individual's identity and an element that connects people into groups (Huddy, 2001). Insofar as people who share the same ideology see each other as peers (Mullen, Dovidio, Craig, \& Copper, 1992) and form groups, it is painful to diverge from the group's political orientation, especially diverging from its main leader. For this reason, people are likely to use their ideological and identity positions as protective lenses that reduce the chances of reevaluating the group's values.

The literature on motivated reasoning suggests that group members interpret information in a way that benefits the group (Bisgaard, 2015; Bolsen, Druckman, \& Cook, 2014; Leeper \& Slothuus, 2014) to reduce the pain generated by information updates that contradict the values on which they rely. Thus, when realizing that a particular position is shared by the community to which they belong, it is expected that its members develop their own narrative structures as a defense mechanism for that position (Bolsen et al., 2014).

Feelings of attachment generate loyalty to the members of each group and feelings of security and prestige. However, individuals who do not belong to a group develop hostility and aversion to the values and beliefs of this group, considered rival and, potentially, enemies. The intrinsic importance of sharing identities and reciprocal loyalties can be perceived among individuals who belong to a group (in-group), and a distancing of individuals who would be outside that group (out-group), leading to biases in favor of their own group and contrary to the rival (Hameleers, 2016).

The ideology and sense of belonging to a particular group can create a state of blindness in which its members tend to disregard factual information when they contradict the group's identity values (Druckman \& Bolsen, 2011). In addition, the ideological congruence between individuals and the leader of the community they belong can have a dazzling effect, leaving members refractory to arguments and allegations contrary to the group's identity values.

Thus, the group members would be more likely to consider false any claim contrary to the group's dominant beliefs. Therefore, people would tend to reach conclusions that confirm their identity/ ideological bias. However, supporting such distorted conclusions requires minimally reasonable justifications (Kunda, 1990). Some events, however, have such an influence on the lives of individuals that even members of strong identity groups can have their beliefs shaken. The identity/ideology may no longer be sufficient to justify the individual's alignment with the group (Kunda, 1990; Mazar et al., 2008).

It is precisely in these moments that identities become malleable and susceptible to changes. The costs of change, therefore, decrease significantly, and the chances of some members going astray when considering other identity alternatives increase. 


\section{METHODOLOGY AND DESCRIPTIVE STATISTICS}

To study the perception of Brazilians regarding the social distancing policy and the performance of politicians during the pandemic, with the support of the newspaper O Estado de S. Paulo, we conducted an opinion poll between March 28 and April 4, 2020. The questionnaire was released on social networks, especially WhatsApp, and 8,168 responses, were collected. After checking the average response time, we excluded questionnaires that were less than 120 and more than 960 seconds long. We also excluded from the sample those with repeated IP numbers. The final sample was 7,848 valid responses and included the participation of respondents from all Brazilian states, with a greater concentration in São Paulo (44\%), Minas Gerais (7\%), and Rio de Janeiro (6\%).

Of the 7,848 respondents, $50.2 \%$ were female and $49.8 \%$ male. In terms of income profile, $13.5 \%$ earned up to three minimum wages; $14.6 \%$, up to five minimum wages; $22.5 \%$, between three and five minimum wages; $36.3 \%$ have an income greater than 10 thousand reais; and $12 \%$ preferred not to respond. As for the age profile, 5\% were between 18 and 24 years old; 16\%, between 25 and 34; $20 \%$, between $35-44$ and $45-55 ; 27 \%$ between 55 and 65 ; and 10\%, over 65 .

Around $32 \%$ of the respondents classified themselves as being in a COVID-19 risk group, $18 \% \mathrm{knew}$ someone who had the disease in the severe stage, and 7\% knew someone who died. In terms of ideological profile, $37.1 \%$ declared themselves as someone in the 'center;' $30.1 \%$, as center-left and left-wing; and 32.8\%, as center-right and right-wing. With regard to the economic consequences of social distancing measures, $37 \%$ reported that they could cause enormous or total financial loss for their professional activity, and $32 \%$ believe that social distancing will not cause financial damage to their professional activity. ${ }^{3}$

We did not use a probabilistic approach for the selection of the sample and chose not to perform any post-stratification in view of the potential risks of introducing bias for unobservable or unmeasured variables. There are, therefore, limits regarding generalization for the population, especially of univariate or bivariate descriptive results, without the inclusion of additional control variables. In addition, the main demographic variables were well balanced in relation to the population, and those with over-representation of a group - the wealthiest in income and residents of the state of São Paulo - were not relevant predictors.

Respondents were invited to participate in research on perception and behavior in relation to the coronavirus. After consent, everyone responded on: (1) the situation in which they were in relation to social distancing; the financial losses resulting from staying in the situation; the social distancing measures that had been implemented by the state government and the president; if they knew someone infected with COVID-19; (2) who they believed were the authority responsible for pandemic control in Brazil; (3) how they evaluated the actions implemented to control the pandemic by the governors and the president; (4) the degree of agreement with the social distancing policy and how willing they were to follow it; (5) socio-demographic aspects.

The questions were multiple-choice, respondents chose a single option, and the results were presented on a Likert scale. The confidence interval calculated for all means was $95 \%$. To measure the variation of complying with social distancing policies among respondents, with regard to the expected economic damage from the pandemic, and exposure of acquaintances to varying degrees

\footnotetext{
${ }^{3}$ All descriptive statistics are available in Table 2, located in the supplementary material in the following link: https://dataverse.harvard. edu/dataset.xhtml?persistentId=doi:10.7910/DVN/SUN4KZ.
} 
of the virus effects, we used a set of linear regressions with robust standard errors and ordinal logistic regressions. All the details about the data sets and material for replicating the analyses of this work can be found in the supplementary material.

\section{PANDEMIC AND IDEOLOGY}

The study sought to understand the political impact of the pandemic based on how the populations' ideological preferences are connected to their evaluation of President Bolsonaro's and the state governors' performance during the pandemic, especially with regard to social distancing and how long the restrictions that aimed to promote social distancing would be in place. The choice for these aspects intended to identify whether clear and polarized ideological inclinations were aligned with the proposed solutions to face the pandemic in Brazil, or whether political polarization has lessened in view of the risks of contracting the disease with varying degrees of severity.

The first point to be highlighted is that the respondents who considered themselves as left-wing, center-left, and center disagree homogeneously with Bolsonaro and support the governors. On the other hand, respondents from the center-right and right-wing, supposedly the core of the president's voters, differ considerably over the evaluation about the support, showing a break in a supposedly previous unity (Figure 1). A greater proportion of these voters (56\%) remained aligned with the president, but $40 \%$ disapproved of his performance in the pandemic, while $5 \%$ were indifferent. The division right-wing and center-right voters was more evident in the assessment of the performance of governors, in which the majority (60\%) agreed, a smaller portion disagreed (35\%), and 5\% were indifferent.

\section{FIGURE 1 ASSESSMENT OF THE PRESIDENT AND GOVERNORS (PER IDEOLOGY)}
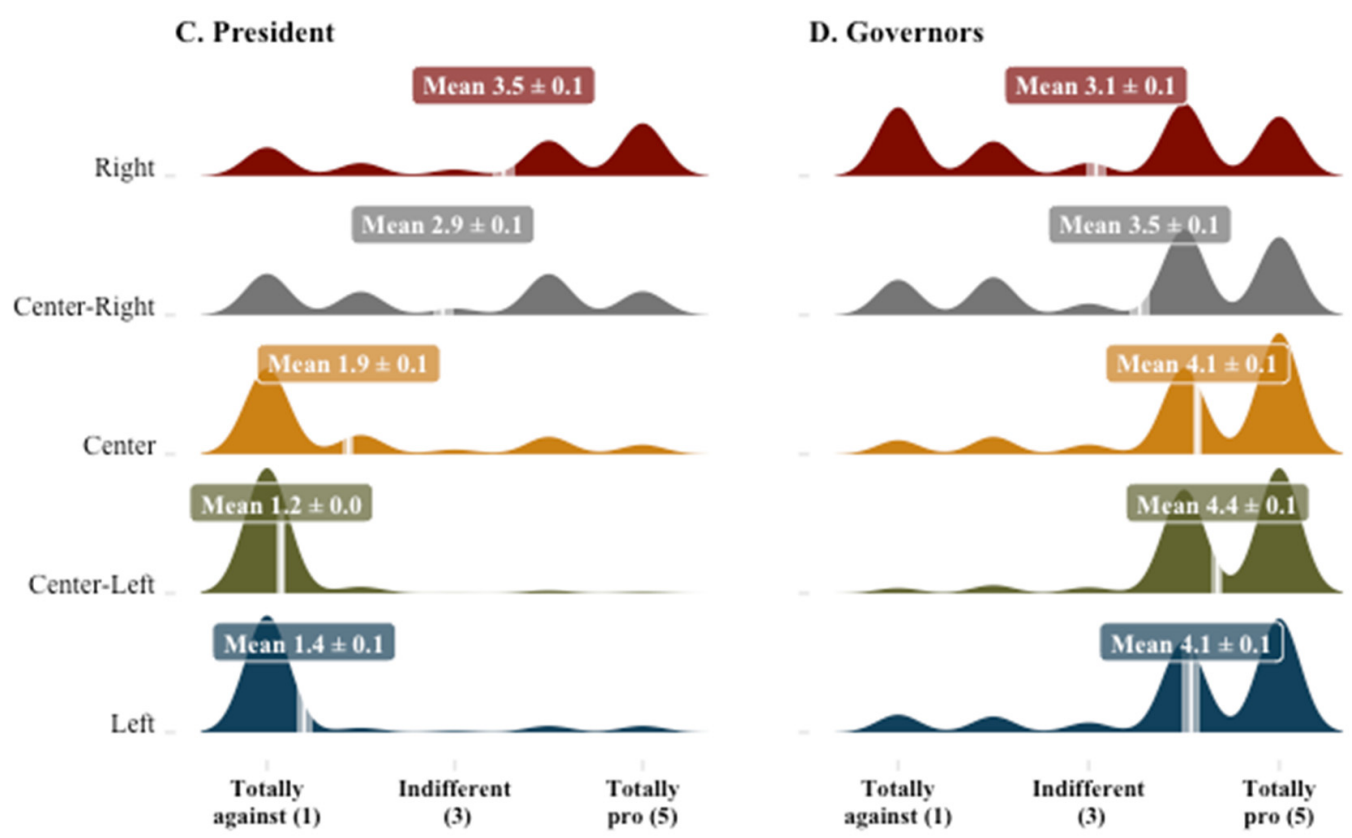

Source: Research data. 
The results indicate that the diametrically opposite way in which Bolsonaro - minimizing the severity of the disease and highlighting the negative economic impacts that the social distancing policy potentially brings - and the governors - prioritizing social distancing policies to reduce the speed of contagion - reacted to the pandemic redesigned the previous political polarization. A considerable part of the individuals who supported the president went to the opposite pole, breaking the bi-modal pattern, characteristic of polarized scenarios (Bello, 2019). This does not necessarily mean that people have completely changed the lens through which they view the world or their political ideology/ identity. It shows, however, that the pandemic may have repositioned the main axis of polarization between those who identify themselves as right-wing and center-right, moving it beyond the simple direct antagonism toward the left-wing.

\section{FIGURE 2 ASSESSMENT OF SOCIAL DISTANCING (PER IDEOLOGY)}

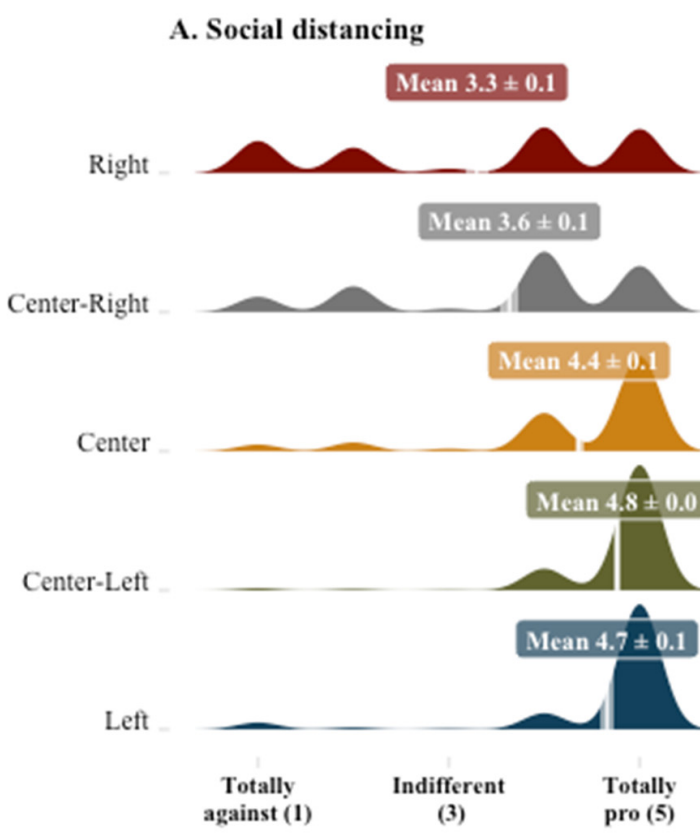

B. Time in Social distancing

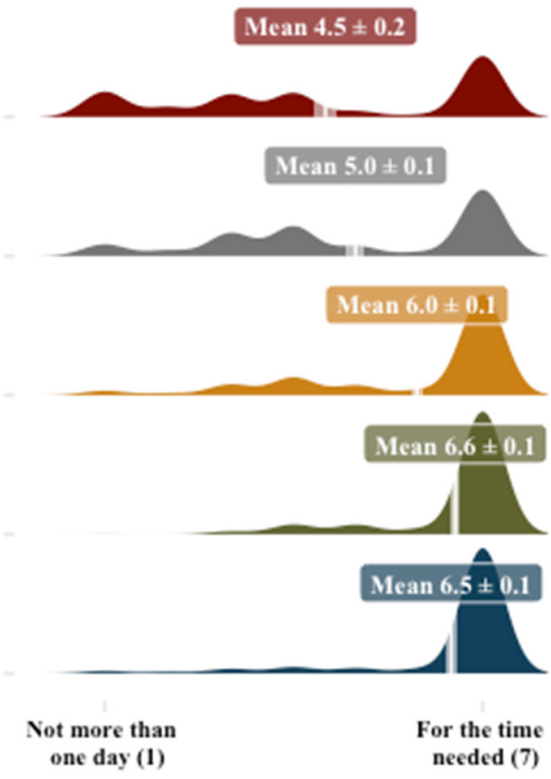

Source: Research data.

This alternative pattern of preference distribution becomes clear when we cross the respondents' position in relation to the social distancing policy, with their respective political-ideological positions (Figure 2). Left-wing, center-left, and center respondents are largely in favor of social distancing for as long as necessary. However, a considerable portion of voters who call themselves center-right and right-wing is also in favor of this policy, contrary to the president's position and recommendation to relax social distancing measures. The results suggest that, in addition to the pre-existing ideological antagonism, most of the right-wing supporters do not agree with the president's view on social distancing. It is essential, therefore, to understand the elements that determine the change in the polarization axis (which occurs fundamentally among voters from the right-wing and center-right). 


\section{A DIVIDED RIGHT-WING: IS SOCIAL DISTANCING ONLY FOR THE RICH?}

The interpretation that the adoption of social distancing is supported mainly by those with sufficient financial resources to remain comfortably in quarantine has gained strength. The assumption, reinforced by Bolsonaro, is that it would be more viable for the higher-income social group to prioritize health care and consider the economic problems generated by the pandemic as secondary. Meanwhile, families in a more vulnerable economic situation would need to return to work and would thus be more resistant to maintaining social distancing (Jorge, 2020).

FIGURE $3 \quad$ POSITION ON SOCIAL DISTANCING (PER INCOME, IN MINIMUM WAGES - MW)

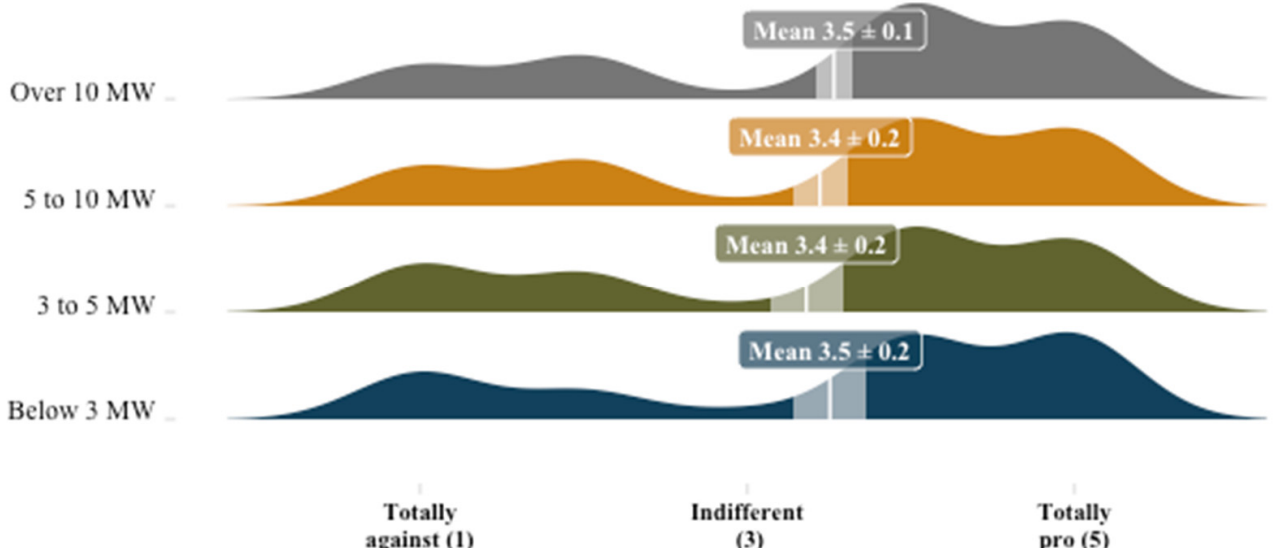

Source: Research data.

In order to verify this argument, we tested whether the apparent antagonism toward social distancing is based on income differences. Figure 3 shows that, contrary to the expectation that people with different incomes (analyzed in groups) should exhibit different patterns of support for the policy, there was no such statistical distinction. Therefore, at least until the week in which the data were collected, society was not divided by income. The poorest and the richest mostly support social distancing and oppose the president's recommendation to return to work.

For people in the upper strata, the reasoning is clear. Since they have the means to protect their income, social distancing would have a lesser cost. But what about the poorest? How is their preference for social distancing explained? We believe that the argument that those most in need would be more opposed to the policy confuses 'preferences' and 'decisions.' The data show that, for most of them, staying at home is strictly preferable to going to work. However, as the federal executive does not credibly show signs that it is committed to offering economic support, individuals observe such signs and establish a set of beliefs about the likelihood of receiving support. In this scenario, low-income people can act strategically and choose, in a rational way, to resume professional activities. However, this does not mean a sincere preference for breaking social distancing. 
As Shah, Shah, Mullainathan, and Shafir (2012) suggest, scarcity changes the way people allocate their attention, causing them to become more deeply involved in some problems while neglecting others. Thus, scarcity in any of its forms of manifestation - hunger, loneliness, lack of time, and poverty - would gain our attention, self-control, and long-term planning capacity, directing the focus to the most immediate object missing. This is the situation of the poorest in the pandemic. Faced with the threat of death, they prefer to stop working and practice social distancing. However, the lack of resources for food and housing takes the focus away from social distancing and leads them to act in order to supply the most immediate needs.

\section{FEAR OF DEATH BRINGS THE POLES TOGETHER}

The behavior of right-wing and center-right voters in relation to social distancing is revealing, particularly taking into account the proximity to people (friends, relatives, etc.) who were infected and developed COVID-19 with varying degrees of severity. Figure 4 shows that the greater the severity of the disease in their acquaintances, the greater the spectrum of "fear of death," and the higher the support for social distancing, for as long as needed.

\section{FIGURE 4 ASSESSMENT OF SOCIAL DISTANCING PER PROXIMITY WITH INFECTED PERSONS (ONLY RIGHT-WING AND CENTER-RIGHT)}

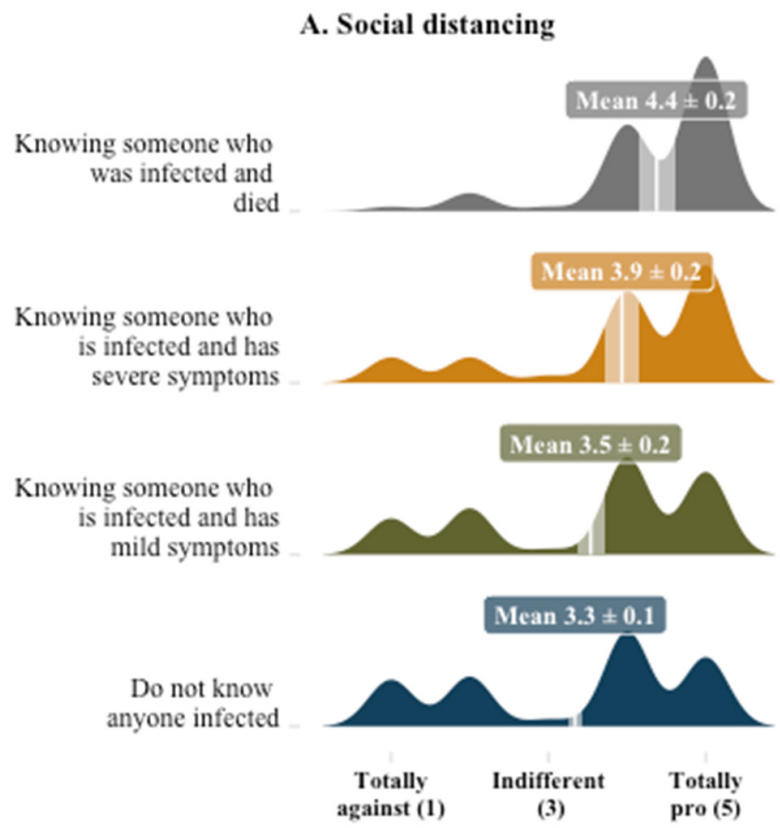

B. Time in Social distancing

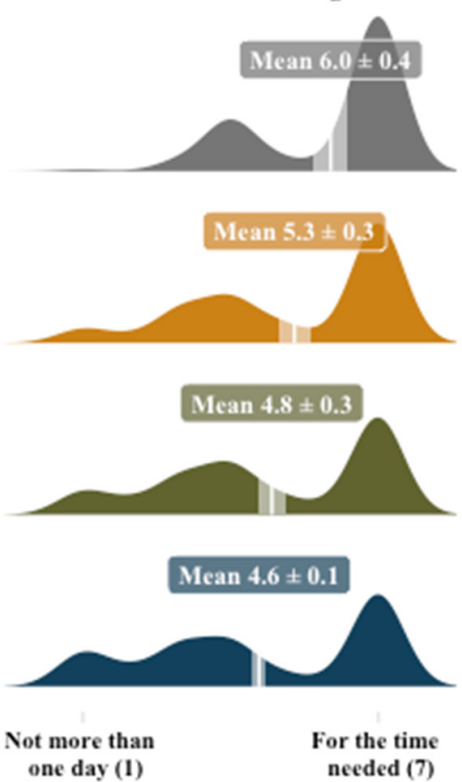

Source: Research data. 


\section{FIGURE $5 \quad$ ASSESSMENT OF POLITICIANS PER PROXIMITY WITH INFECTED PERSONS (ONLY RIGHT-WING AND CENTER-RIGHT)}
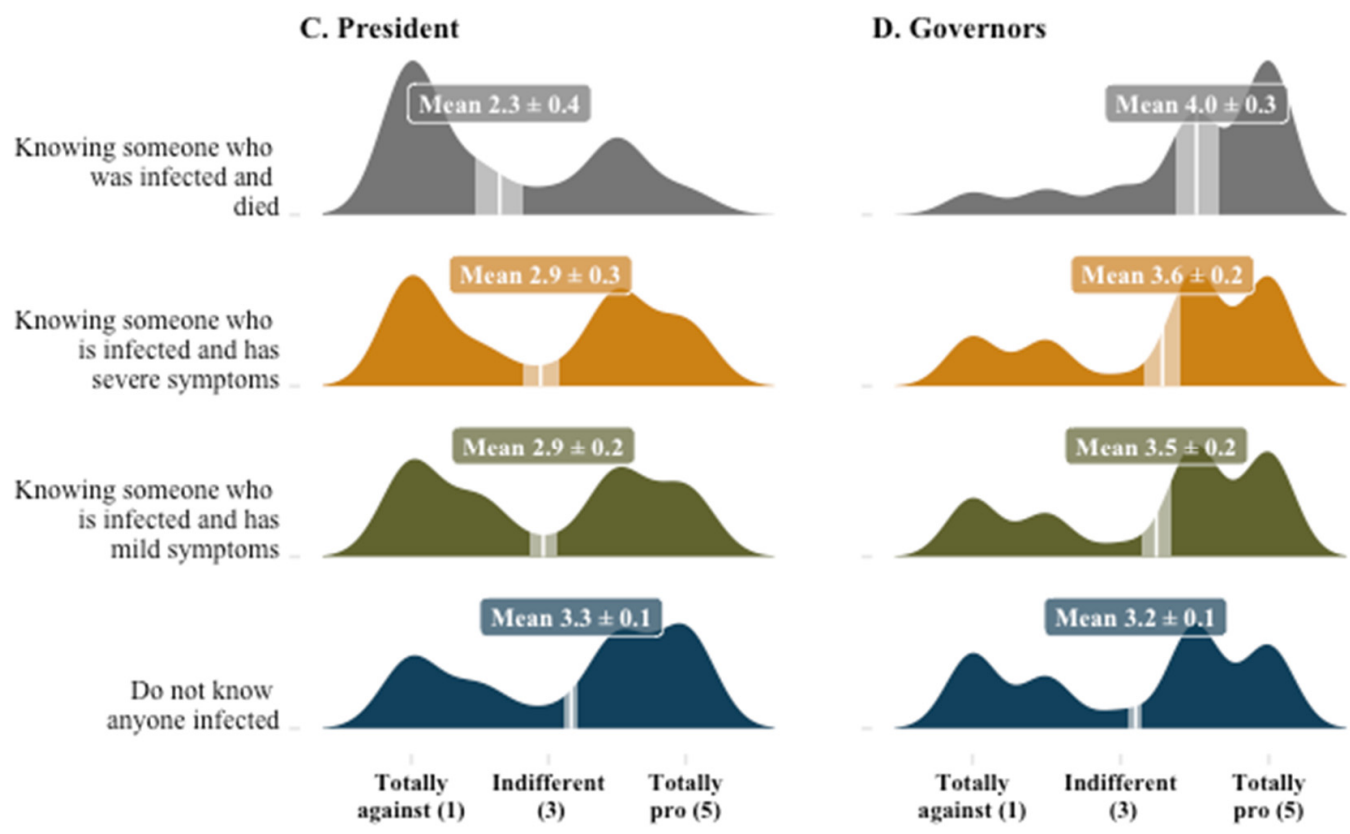

Source: Research data.

The effect of proximity to the risk of death associated with COVID-19 is also seen in the respondents' evaluation of the performance of the president and governors. The greater the exposure to the risks of the virus, the less people agree with Bolsonaro and more with the governors (Figure 5). This is evidence that reinforces the hypothesis that the identity bonds between right-wing and center-right voters and Bolsonaro became more malleable the closer these voters are to people who developed the disease, especially if they know someone who dies from it. Thus, given the weakening of identity connections, the costs of changing the position of these voters in relation to the government have decreased.

As observed before, the income did not affect the respondents' support for social distancing measures. But what about the economic loss they may generate? Figure 6 shows the distribution of the different levels of economic loss as a result of supporting the president's recommendation to make social distancing more flexible, correlated with the knowledge of people infected with COVID-19, and their respective degrees of severity. 
FIGURE 6 RELATIONSHIP BETWEEN SOCIAL DISTANCING AND THE POTENTIAL ECONOMIC EFFECTS (PER PROXIMITY WITH INFECTED PERSONS)

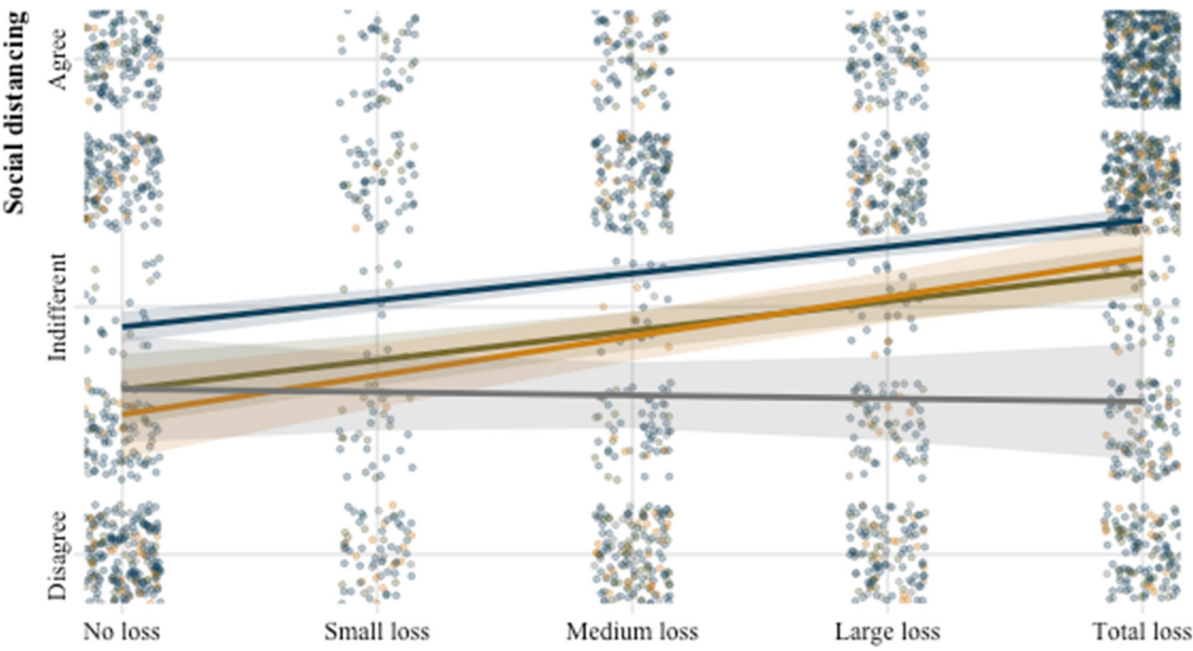

Personal economic loss

\section{Proximity with infected persons}

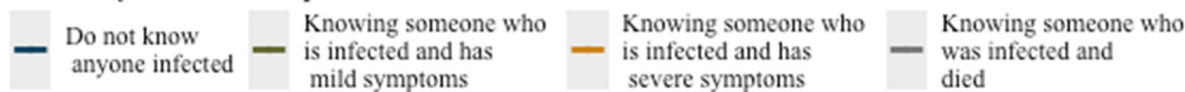

Source: Research data.

Although there is a negative relationship between expected economic loss and support for social distancing, levels of proximity to the disease make a difference in this relationship. For those who do not know infected people, the greater the economic impact, the less support for social distancing. However, among those who know people who have died, this variation does not occur. In other words, the seriousness of the contamination that can cause death leads people to minimize the potential economic losses. The fear of death seems to not only bring together ideologically opposed poles, but also different social classes and people who are experiencing different levels of economic loss as a result of the policy. The results are also consistent for supporting the president in the opposite direction to supporting social distancing and governors.

Simply put, it is possible to identify two groups of Bolsonaro supporters: the group based on identity and the 'pragmatists.' The first one is organic and formed by people who believe in the president's political project. In order to remain cohesive, and keep offering basic and secure social support, this group needs to be constantly fed with populist and polarized agendas. The second group, on the other hand, supports the president, believing that his government has the capacity to meet the group's agenda, which includes liberal economic policies, combating corruption, and containing the Worker's Party. ${ }^{4}$

\footnotetext{
${ }^{4}$ Although our data do not allow us to test this assumption directly, it finds relative theoretical and empirical support in the literature on cultural wars (Hunter, 1991; Laclau, 2013; Lakoff, 1996). Specifically in the Brazilian context, data from interviews collected during the demonstrations of March 25 and 31, 2017, by Gallego, Ortellado, and Moretto (2017), suggest that the biggest factors uniting the group of 'pragmatists,' self-declared right-wing and conservatives, were the 'anti-corruption' debate and the discourse 'anti-PT.' The voters in this group, however, did not show unity around a moral agenda, which indicates a less obvious coordination, but consistent with the existence of a subgroup with more progressive moral values; another subgroup more conservative punitive; and a third, with a conservative religious profile. Such agendas can be observed in research conducted by Datafolha in October 2018 among the reasons for voting for Bolsonaro. A desire for political renewal and anti-PT brought together 55\% of the motivations for voting for the candidate, while reasons linked to the candidate's personal image and values made up $13 \%$ of his voters.
} 
The group of Bolsonaro's electorate considered as 'pragmatists', was already withdrawing their support to the president due to his belligerent attitudes and because he did not seem to meet their expectations. While he radicalized on issues related to the environment, gender, minorities, foreign policy, education and culture, his right-wing voters were willing to continue to support him, since they believed their individual short-term risks of loss were low. However, when the president took a stand against the policy of social distancing, with the aim of mitigating economic consequences, the respondents interpreted that this position posed risks to their own lives and that of loved ones, generating real risks in the short term.

The effects of Figure 6 can also be identified by means of linear estimation. The dependent variable is supporting the social distancing policy. We estimated, only for respondents who called themselves right-wing and center-right, different models of the relationship between exposure to COVID-19 and social distancing. Our preferred estimation is expressed as:

$$
\begin{gathered}
\text { social distancing }=\alpha+\beta_{1} \text { covid }+\beta_{2} \text { loss_dummy }+\beta_{3} \text { sex }+\beta_{4} \text { age }+\beta_{5} \text { income }+ \\
\beta_{6}\left(\text { covid }{ }^{*} \text { loss_dummy }\right)+\epsilon
\end{gathered}
$$

The explanatory variables of the tested models are: 1) "fear of death" proxies (variable called 'covid' in our model), measured by the proximity of respondents to people contaminated by COVID-19 and their different degrees of severity ('do not know,' 'mild,' 'severe,' and 'death'); and 2) expectation of economic loss due to social distancing, measured by a Likert scale from 1 to 5 . As control variables, we included the different income, sex, and age groups - people over 45 years old, as it was from that age group that we found a greater variance in preferences. In addition, in some of the models, we included interactions between "fear of death" and "economic loss."

We operate the 'covid' variable in two different ways: as a quantitative variable (covid num) and as an ordinal qualitative variable (covid), with four levels. The loss variable was operationalized as a dummy (loss dummy) because only the category of total loss shows a difference in the average support for social distancing in relation to the others. Table 1 shows the results of the estimates with robust standard errors.

\begin{tabular}{|c|c|c|c|c|}
\hline & Model 1 & Model 2 & Model 3 & Model 4 \\
\hline Covid_num & $0,22^{* * *}(0,03)$ & & 0,20 *** $(0,03)$ & \\
\hline Loss_dummy & $-0,73^{\star * \star}(0,07)$ & $-0,81^{\star \star \star}(0,08)$ & $-0,71^{\star * *}(0,07)$ & $-0,80^{* * *}(0,08)$ \\
\hline Covid_num: Loss_dummy & $0,14 *(0,06)$ & & $0,16 *(0,06)$ & \\
\hline Covid Mild & & $0,22 *(0,09)$ & & $0,16(0,09)$ \\
\hline Covid Severe & & $0,47^{\star \star *}(0,12)$ & & $0,42^{* \star \star}(0,12)$ \\
\hline Covid Death & & $0,87^{\star \star \star}(0,11)$ & & $0,81^{\star \star \star}(0,11)$ \\
\hline Covid Mild: Loss_dummy & & $0,10(0,18)$ & & $0,13(0,18)$ \\
\hline Covid Severe: Loss_dummy & & $0,43 *(0,21)$ & & $0,48 *(0,21)$ \\
\hline Covid Death: Loss_dummy & & $0,52(0,35)$ & & $0,56(0,33)$ \\
\hline Sex Male & & & $-0,53^{\star * \star}(0,06)$ & $-0,54^{\star * \star}(0,06)$ \\
\hline Income 3 to $5 \mathrm{MW}$ & & & $-0,08(0,11)$ & $-0,08(0,11)$ \\
\hline Income 5 to $10 \mathrm{MW}$ & & & $-0,07(0,10)$ & $-0,06(0,10)$ \\
\hline Income over $10 \mathrm{MW}$ & & & $-0,01(0,09)$ & $0,01(0,09)$ \\
\hline Age & & & $-0,27^{\star \star \star}(0,06)$ & $-0,27^{\star \star \star}(0,06)$ \\
\hline $\mathrm{N}$ & 2126 & 2126 & 2126 & 2126 \\
\hline $\mathrm{R}^{2}$ & 0,09 & 0,09 & 0,13 & 0,14 \\
\hline
\end{tabular}

\section{TABLE $1 \quad$ EXPLANATORY MODEL OF THE PREFERENCE FOR SOCIAL DISTANCING}

All continuous predictors are centered on the mean and resized to 1 standard deviation. Standard errors are heteroskedasticity-consistent. ${ }^{* *} \mathrm{p}<0,001 ;{ }^{\star *} \mathrm{p}<0,01 ;{ }^{\star} \mathrm{p}<0,05$.

Source: Research data. 
Table 1 and Figure 7 show that our hypothesis has been confirmed. The degree of proximity to someone contaminated by COVID-19 increases the chances of supporting social distancing, i.e., the support increases with the perception of proximity to the risk of death. In other words, the fear of death brought about by the pandemic is strong enough to weaken the identity/ideological ties between this group of voters and the president to the extent that these voters contradict their leader and consistently support social distancing. Keeping the other variables constant, it is possible to infer that those who know someone who died from COVID-19 agree with the social distancing policy at a level of $19.20 \%$ higher than those who do not know people infected by the virus. As we have shown, the different income groups have no significant statistical impact on social distancing. However, those with expectations of economic loss, older people, and men tend to support social distancing less. ${ }^{5}$

\section{FIGURE 7 EXPLANATORY MODELS OF PREFERENCE FOR SOCIAL DISTANCING}

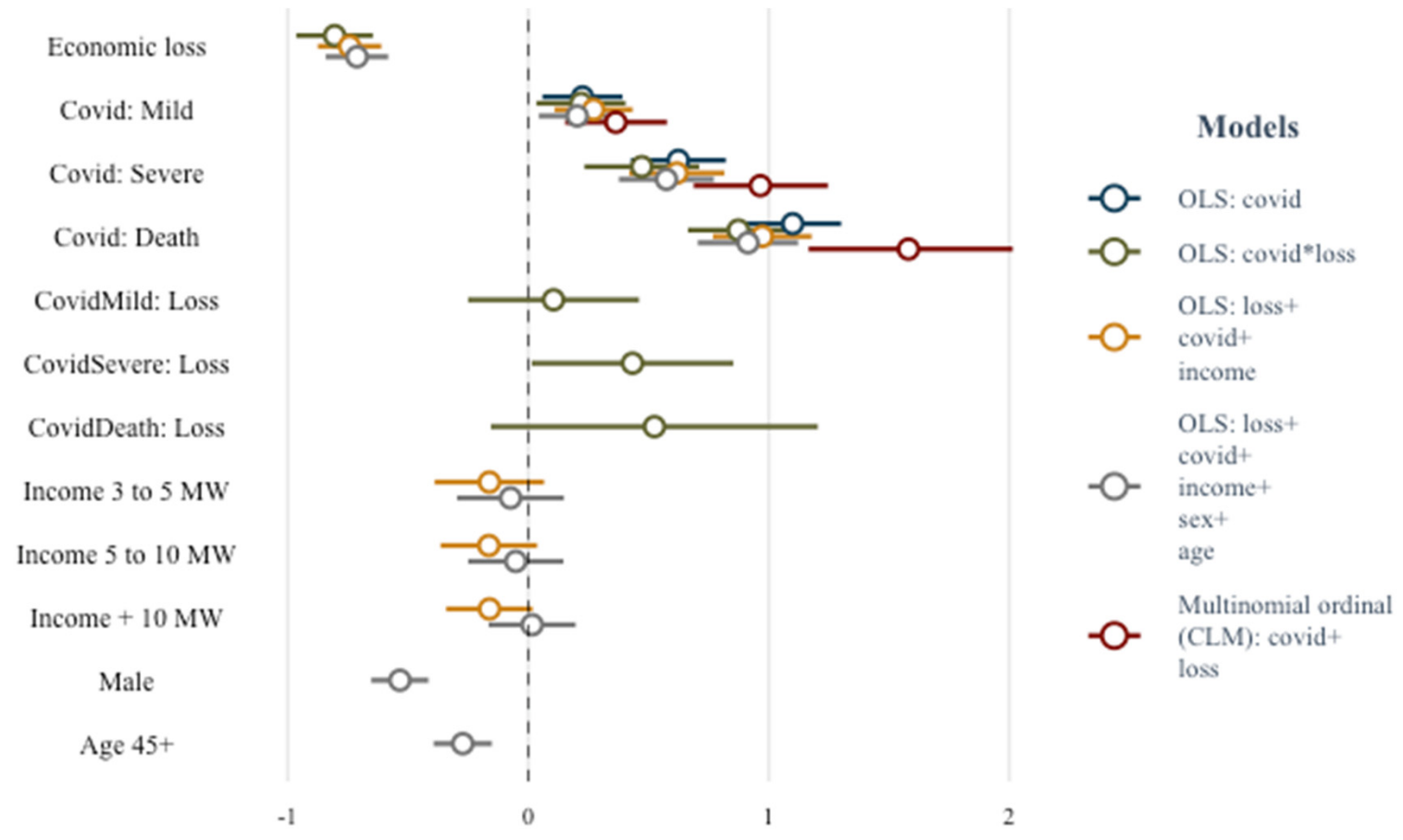

Estimate: Social distancing

Source: Research data.

\footnotetext{
${ }^{5}$ Additional specifications and information for replicating regressions can be found in the supplementary material (https://dataverse. harvard.edu/dataset.xhtml?persistentId=doi:10.7910/DVN/SUN4KZ).
} 


\section{CONCLUSION}

Severe crises, such as wars or pandemics, may be unique opportunities for government leaders willing to leave a legacy, to show their capacity to unite and lead the country against a common enemy. Bolsonaro, however, seems unable to leave behind the obstacles he created, himself, when he decided to rule as a minority without a coalition government. For the president, this was a missed opportunity. The results confirm he was one of the few world leaders who lost support and popularity with voters (see Figure 8 in the supplementary material).

Even though he was put down for preferring to implement a perpetual polarized campaign, the president had been able to maintain the popularity and political support of a significant portion of the population. However, by emphasizing the negative impacts of social distancing on the economy and, at the same time, minimizing the risks of contagion and seriousness of the pandemic, even the significant portion of voters who were aligned with the government based on identity and ideology, decided to withdraw their support.

Bolsonaro did not realize that the population's fear of losing lives with the new coronavirus outweighs the risks of economic crisis, as he did not realize that people tend to discount the future. In other words, today's concerns are always greater than those to come. Bolsonaro contradicted the population's desires, and signs of rejection among followers began to appear. The protests, inquiries about the president's interference in government control agencies, and the various requests for impeachment are evidence of this rejection.

Our research revealed that as the individuals in the sample became aware of fatal victims among their acquaintances, their perceptions changed. They became more favorable of social distancing and willing to follow such policy for longer. Also, the respondents evaluated the president's performance as 'worse' and the governors' as 'better.' Thus, the identity connections between the group and its leader became malleable and fragile.

It is worth noting that this study collected the data analyzed amidst the pandemic, in a period of high transmission, and many deaths. On the one hand, we were able to capture the feeling of "fear of death" and its influence on political behavior. On the other, this feeling may have inflated people's reactions, which could represent a limitation. In addition, the lack of probabilistic sample design limits the generalization of the findings.

While recognizing the research limitations, its results offer relevant insights. The study suggests that political leaders who put effort into fighting the pandemic may obtain greater benefits than those more concerned with preventing economic downturn. The group recognized as right-wing was divided, but not because of income. The polarization reduces as the risk of death becomes more present. The fear of death is so intense that it relativizes and overcomes the losses of identity related to the ideology 


\section{REFERENCES}

Ajzenman, N., Cavalcanti, T., \& Da Mata, D. (2020, April 22). More than words: Leaders' speech and risky behavior during a pandemic. SSRN. Retrieved from https://papers.ssrn.com/sol3/papers. cfm?abstract_id=3582908

Bakker, B., Rooduijn, M., \& Schumacher, G. (2016). The Psychological Roots of Populist Voting: Evidence from the United States, the Netherlands and Germany. European Journal of Political Research, 55(2), 1-58.

Bello, A. (2019). Origens, causas e consequências da polarização política. Brasília, DF: Universidade de Brasília.

Bisgaard, M. (2015). Bias will find a way: economic perceptions, attributions of blame, and partisanmotivated reasoning during crisis. The Journal of Politics, 77(3), 849-860.

Bos, L., Schemer, C., Corbu, N., Hameleers, M., Andreadis, I., Schulz, A., ... Fawzi, N. (2020). The effects of populism as a social identity frame on persuasion and mobilisation: evidence from a 15-country experiment. European Journal of Political Research, 59(1), 3-24.

Bolsen, T., Druckman, J. N., \& Cook, F. L. (2014). The influence of partisan motivated reasoning on public opinion. Political Behavior, 36(2), 235-262.

Busby, E. C., Gubler, J. R., \& Hawkins, K. A. (2019). Framing and blame attribution in populist rhetoric. The Journal of Politics, 81(2), 616-630.

Conaghan, C. M. (2008). Ecuador: Correa's plebiscitary presidency. Journal of Democracy, 19(2), 46-60.

Druckman, J. N., \& Bolsen, T. (2011). Framing, motivated reasoning, and opinions about emergent technologies. Journal of Communication, 61(4), 659-688

Hameleers, M., Bos, L., \& Vreese, C. H. (2017). “They did it": The effects of emotionalized blame attribution in populist communication. Communication Research, 44(6), 870-900.

Hawkins, K. A., Kaltwasser, C. R., \& Andreadis, I. (2020, April). The Activation of Populist Attitudes. Government and Opposition, 55(2), 283-307.
Huckfeldt, R., Levine, J., Morgan, W., \& Sprague, J. (1999). Accessibility and the political utility of partisan and ideological orientations. American Journal of Political Science, 43(3), 888-911.

Huddy, L. (2001). From social to political identity: a critical examination of social identity theory. Political Psychology, 22(1), 127-156.

Hunter, W., \& Power, T. J. (2019). Bolsonaro and Brazil's illiberal backlash. Journal of Democracy, 30(1), 68-82.

Iborra, A. (2005). Beyond identity and ideology: processes of transcendence associated with the experience of conversion. Culture and Psychology, 11(1), 89-100.

Jorge, M. P. (2020). Quarenta é coisa de rico?. Retrieved from https://www.youtube.com/ watch?v=KRcNNWHM2EY

Kernell, S. (2006). Going public: new strategies of presidential leadership. Washington, DC: CQ Press.

Kingstone, P., \& Power, T. J. (2017). Democratic Brazil divided. Pittsburgh, Pennsylvania: University of Pittsburgh Press.

Kovic, M., \& Caspar, C. (2019, January 11). Motivated cognition, conspiratorial epistemology, and bullshit: a model of post-factual political discourse politics. Retrieved from https://doi.org/10.31235/ osf.io/bnv2m

Kunda, Z. (1990). The case for motivated reasoning. Psychological Bulletin, 108(3), 480-498.

Leeper, T. J., \& Slothuus, R. (2014). Political parties, motivated reasoning, and public opinion formation. Political Psychology, 35(S1), 129-156.

Martins, P. (2020, April 24). Painel debate falso dilema entre salvar a economia ou a saúde durante a pandemia. ABRASCO. Retrieved from https://www. abrasco.org.br/site/sem-categoria/painel-debatefalso-dilema-entre-salvar-a-economia-ou-a-saudedurante-a-pandemia/47292/

Mazar, N., Amir, O., \& Ariely, D. (2008). The dishonesty of honest people: a theory of self-concept maintenance. Journal of Marketing Research, 155(6), 633-644.

Mudde, C. (2004). The Populist Zeitgeist. Government and Opposition, 39(4), 541-563. 
Mudde, C., \& Kaltwasser, C. R. (2012). Exclusionary vs. Inclusionary Populism: Comparing Contemporary Europe and Latin America. Government and Opposition, 48(2), 147-174.

Mullen, B., Dovidio, J. F., Craig, J., \& Copper, C. (1992). In-group out-group differences in social projection. Journal of Experimental Social Psychology, 28(5), 422-440.

Pereira, F. (2020, May 08). "Não é o isolamento que afeta a economia, é a pandemia", diz Meirelles. UOL. Retrieved from https://economia.uol.com.br/noticias/ redacao/2020/05/08/nao-e-o-isolamento-que-afetaa-economia-e-a-pandemia-diz-meirelles.htm

Samuels, D., \& Zucco, C. (2018) Partisans, antipartisans and nonpartisans: voting behavior in Brazil. Cambridge, UK: Cambridge University Press.

Shah, A. K., Mullainathan, S., \& Shafir, E. (2012). Some consequences of having too little. Science, 338(6107), 682-685.

Teles, C. D. P. (2009). Linguagem escolar e a construção da identidade e consciência racial da criança negra na educação infantil. Anagrama - Revista Científica Interdisciplinar da Graduação, 1(4), 1-14.

\section{Carlos Pereira}

https://orcid.org/0000-0002-8978-1493

Ph.D. in Political Science; Full Professor at the Brazilian School of Public and Business Administration at Fundação Getulio Vargas (FGV EBAPE). E-mail: carlos.pereira@fgv.br

\section{Amanda Medeiros}

https://orcid.org/0000-0002-0008-3905

Ph.D. in Administration; Professor at the Brazilian School of Public and Business Administration at Fundação Getulio Vargas (FGV EBAPE). E-mail: amanda.medeiros@fgv.br

\section{Frederico Bertholini}

https://orcid.org/0000-0002-2480-739X

Ph.D. in Administration; Adjunct Professor at the Institute of Political Science of the University of Brasília (IPOL/UNB).E-mail: frederico.bertholini@unb.br 